Website:http://bcsdjournals.com/index.php/jsrmbs ISSN 2709-0159 (Print) and 2709-1511 (Online)

Vol 2, Issue 3, 2021

DOI: https://doi.org/10.47631/jsrmbs.v2i3.304

\title{
In vitro Antimicrobial Activity of Ethanolic Leaf Extracts of Hibiscus Asper Hook. F. and Hibiscus Sabdariffa L. on some Pathogenic Bacteria
}

\author{
Joseph Olowo Arogbodo ${ }^{1}$, Oyetayo Bolanle Faluyi ${ }^{1}$, Festus Omotere Igbe ${ }^{2}$ \\ ${ }^{I}$ Department of Animal Production and Health, Federal University of Technology, Akure, Nigeria \\ ${ }^{2}$ Department of Bio-Chemistry, Federal University of Technology, Akure, Nigeria
}

\begin{tabular}{|c|c|}
\hline Article Info & Abstract \\
\hline Article history: & Purpose: The study aims to assess the antimicrobial activity of ethanolic \\
\hline Received:07 May 2021 & leaf extracts of Hibiscus asper and Hibiscus sabdariffa against eight \\
\hline 11 July 2021 & bacterial isolates. \\
\hline July 2021 & $\begin{array}{l}\text { Materials and Methods: An in vitro Antimicrobial activity of ethanolic leaf } \\
\text { extract of the two plants against eight nosocomical and pathogenic bacteria }\end{array}$ \\
\hline Keywords: & viz; Pseudomonas aeruginosa (PAE), Proteus vulgaris (PVU), Klebsiella \\
\hline Bacteria, Antimicrobial & aerogenes (KAE), Staphylococcus aureus (SAU), Bacillus cereus (BCE), \\
\hline Resistance, Inhibition & Escherichia coli (ECO), Moraxella catarrhalis (MCA) and Salmonella typhi \\
\hline Zones, H. asper, $H$. & (STY) was carried out using agar well diffusion assay with the concentration \\
\hline Sabdariffa & range of $3.13-100 \mathrm{mg} / \mathrm{mL}$ \\
\hline $\begin{array}{l}\text { Paper Type : } \\
\text { Research Article }\end{array}$ & $\begin{array}{l}\text { Results: } H \text {. asper and } H \text {. sabdariffa showed significant difference }(p<0.05) \\
\text { in antimicrobial activity against BCE over the rest of the isolates. Inhibition } \\
\text { zone diameters exhibited by the isolates to ethanolic leaf extract of } H \text {. asper }\end{array}$ \\
\hline $\begin{array}{l}\text { Correspondence Author } \\
\text { Arogbodo, J.O }\end{array}$ & $\begin{array}{l}\text { was in descending order of } B C E\left(15.00 \pm 1.00^{a}\right)>E C O\left(11.67 \pm 0.58^{b}\right) \\
>S A U\left(7.67 \pm 0.58^{c}\right)>P A E\left(6.67 \pm 0.58^{d}\right)>S T Y\left(5.67 \pm 0.58^{e}\right) \text { while that of } \\
\text { H. sabdariffa was in the order } B C E\left(15.33 \pm 1.15^{a}\right)>M C A\left(11.33 \pm 1.15^{b}\right)\end{array}$ \\
\hline $\begin{array}{l}\text { Email: } \\
\text { arogbodojo@futa.edu.ng }\end{array}$ & $\begin{array}{l}>S A U\left(11.00 \pm 1.00^{b c}\right)>K A E\left(9.67 \pm 0.58^{c}\right)>P A E\left(8.00 \pm 1.00^{d}\right)>P V U \\
\left(7.67 \pm 0.57^{e}\right) . P V U, K A E \text { and } M C A \text { were resistant to the extract of } H . \text { asper } \\
\text { while only STY was resistant to that of } H . \text { sabdariffa. }\end{array}$ \\
\hline & $\begin{array}{l}\text { Conclusion: } H \text {. sabdariffa extract demonstrated higher antimicrobial } \\
\text { activity against the selected bacterial isolates than } H \text {. asper. However, the } \\
\text { two extracts minimum inhibition concentrations (MICs) ranged from } 25 \\
m g / m L \text { to } 12.5 \mathrm{mg} / \mathrm{mL} \text {. This is worthy of further exploration by } \\
\text { pharmacological industries in the formulation of potent broad spectrum } \\
\text { antibiotics for combating the present health challenge due to antimicrobial } \\
\text { resistance. }\end{array}$ \\
\hline
\end{tabular}

\section{Introduction}

Plants are nature's prodigious endowment for human and animals' boundless use. This usage among others encompasses nutritional and medicinal. Most of these plants grow luxuriantly in an attractive lush during raining season but rapidly faded away as soon as dry season sets in. Exploitation of their vast benefits will be a right step in the right direction towards the realization of millennial sustainability goals. Several authors have reported the antimicrobial potentials of medicinal plants overtime with the great possibility of acquiring bioactive compounds in them for drug formulation. According to the report of Ofongo and Ohimain (2019) aqueous extract of Azadirachta indica (neem) and Vernonia amygdalyna 
(bitter leaf) were highly effective in lowering the population of enteropathogenic bacteria ( $E$. coli and Salmonella) in the gut of broiler chickens. Averrhoa carambola otherwise called Star fruit is a sweet juicy and succulent fruit that is cherished and consumed by many people. The juice extract is also used in folkloric medicine in the treatment of certain ailments such as skin rashes, inflammatory conditions and diabetes. Oladipo et al. (2019) reported that the use of methanolic extract of Annona muricata bark led to gradual reduction in the blood sugar level. The plant showed a great potential when compared to standard anti-diabetic drug in the treatment of diabetes mellitus. Wumnokol et al. (2019) reported the inclusion of Acha (Digitaria exilis Staph) in the diet of broiler chickens as beneficial on the haematological parameters. It was reported by Ukorebi et al. (2019) that 10\% dietary level of Gongronema latifolia (Utasi) supported normal health by enhancing the blood building capacity and performance of broiler chickens.

Hibiscus asper Hook. F. as reported by Baerts and Lehmann (2002) and Sunilson et al., (2009) is a tropical plant belonging to the family Malvaceae of the order Malvales. Calyxes from $H$. asper are edible as a palatable vegetable after boiling. The plant has medicinal potentials to treat joint pain, anaemia, jaundice malaria, painful, irregular menstruation, leucorrhea, poison antidote, depression, gastrointestinal disorders, abscesses, urethritis, and dysmenorrhea (Burkill, 1985; Shippers et al., 2004; Foyet et al., 2011). The plant is also relevant in veterinary medicine for the treatment of ecto-parasites (Hritcu et al., 2011). Prepared aqueous and methanolic extracts of the leaf of $H$. asper possess significant antidiarrheal activity in experimented rats while the methanolic fraction had antibacterial activity on human enterobacteria (Ateufack et al., 2014). Hibiscus sabdariffa (Roselle) belongs to the same family with $H$. asper and probably native to West Africa (Encyclopedia Britannica, 2020) and grown for its edible calyx. This plant is a good source of lipid-soluble antioxidants, (gamma-tocopherol) polyphenols, flavonoids, and their derivatives (Mohamed et al., 2007 and Jing et al., 2015). It possesses the pharmacological potentials of being antiviral, anticancer, antimicrobial, antifungal, anti-anaemic, hypotensive, anti-urolithiasis etc. (Bireswar \&Charu, 2018). The two plants are rich in phytochemicals and this might probably be responsible for their potent medicinal values recorded in literatures.

Pseudomonas aeruginosa is of the family pseudomonadaceae. It is a very common Gram negative bacterium implicated to be one of the causative agents of nosocomical infections. It is an opportunistic bacterium that is highly resistant to many commercial disinfectants (Hugo\&Russel, 1998; Verma et al., 2014). Proteus vulgaris has been documented as one of the zoonotic pathogenic bacteria that are multi-drug resistant and this can be traceable to drug abuse and indiscriminate prescriptions of antibiotics. It is a Gram-negative bacterium in the family enterobacteriaceae that has been reported as a disease causing agent in poultry and humans (Debasis et al., 2015; Ogunleye\&Carlson, 2016). Klebsiella aerogenes, (formerly known as Enterobacter aerogenes) is an important opportunistic Gram-negative rod-shaped pathogenic bacterium in the family Enterobacteriaceae with drug resistance characteristics. The bacterium has been commonly reported as one the causative agent of disease outbreaks in intensive care unit with high epidemic potential (Adel et al., 2019). Staphylococcus aureus is a Gram-positive bacterium implicated as a coloniser of the pharynx and nasal cavity causing endocarditis, bacteremia etc. Its infection is not limited to a particular site of the body and can also cause food poisoning (Shamshul et al., 2019). Bacillus cereus is a spore forming motile 
Gram-positive bacterium causing two major types of food poisoning through its production of one emetic toxin and three different enterotoxins: the emetic type normally results into vomiting and the other type culminating into diarrhoea (Kramer and Gilbert 1989; Granum 1994; Lund\& Granum 1997; Per\&Terje, 1997). B. cereus is one of the bacteria responsible for the possible risk of food-borne infections/intoxications in both plant and animal food origin. This organism found these food sources to be favourable substrates for its development and replication (Ana et al., 2019). Escherichia coli (a rod-shaped Gram-negative bacterium) is from the family Enterobacteriaceae within the class Gammaproteobacteria (Jang et al., 2017). E. coli comprises commensal and pathogenic strains responsible for several human ailments aggravating to millions of deaths annually (Kaper et al., 2004). Many of the water borne outbreaks in the World have been attributed to Shiga toxin-producing and enteropathogenic $E$. coli (Chandran\& Mazumder, 2015). Moraxella catarrhalis is a pathogenic gram-negative bacterium coccus of the Neisseriae family usually colonises the upper respiratory tract and thereby causing infection ranging from otitis media in children and downstream respiratory infection in adult. This bacterium has become greatly resistant to penicillin antibiotic (Savitha et al., 2020). Salmonella typhi is a Gram-negative, aerobic, rod-shaped bacterium known to be involved in salmonellosis and the disease is usually contracted in contaminated food stuffs (especially in meat) by this organism (Yang et al., 2010). Salmonellosis is a worldwide disease that is zoonotic and causing gastroenteritis in human (Lee, 2015). Stale air and overcrowded environments are predisposing conditions for spreading the disease. The diseases caused by these pathogenic bacteria, coupled with their resistance to many available commercial antibiotics and the dearth of information concerning the utilization of the leaf extract of $H$. asper and H. sabdariffa as antimicrobial agents are the considerable factors in designing and carrying out this research work.

\section{Methodology and Procedures}

\section{Collection of experimental plants}

Fresh and disease free leaves of Hibiscus asper and Hibiscus Sabdariffa were harvested in November 2019 from a farm at Goshen Community, off Aule GRA Akure, Nigeria, Latitude 7:16.06N and Longitude 5:8.85E.

\section{Identification and authentication}

The plants were identified and authenticated by an experienced Taxonomist with identification numbers FPI 2278 and FPI 2280 for Hibiscus asper and Hibiscus Sabdariffa respectively at Faculty of Pharmacy Herbarium, Obafemi Awolowo University, Ile-Ife, Nigeria.

\section{Plants' preparation}

The plants were rid of dust particles by gentle rinse in distilled water. Crispiness of the leaves was achieved in eight days under shade drying and thereafter pulverized into powder 
using Bajaj Twister Mixer Electric Grinder (3 Jar QC. NO: HP/14/001/0064). The samples were preserved in air-tight plastic containers at $4^{\circ} \mathrm{C}$ prior to subsequent assignment.

\section{Preparation of the extracts}

Cold maceration method was adopted in the preparation of the leaf extracts. Exactly 50 $\mathrm{g}$ each of the powdered leaves was soaked in $500 \mathrm{~mL}$ of $80 \%$ ethanol (w/v) kept and kept for 72 hours in a tightly sealed plastic container at room temperature. Filtration was done with muslin cloth and later re-filtered with Whatman filter paper No $1(125 \mathrm{~mm})$. The wet extract was concentrated into pasty form using a crude method for bacterial susceptibility test experiment.

\section{Calculation of the leaf processing percentage yield}

The leaf processing percentage yield (LPPY) was calculated using the formula:

$$
\text { LPPY }=\frac{\text { Dry weight }}{\text { Fresh weight }} \times 100
$$

\section{Test Microrganisms}

Clinical strains of Pseudomonas aeruginosa, Proteus vulgaris, Staphylococcus aureus, Moraxella catarrhalis and Salmonella typhi were obtained from the Microbiology Department of a reputable Specialist Hospital in Akure, Ondo State, Nigeria while Bacillus cereus, Escherichia coli and Klebsiella aerogenes (formerly Enterobacter aerogenes) were isolated from drinking water from Ekiti State, Nigeria. The organisms were carefully maintained on nutrient slants at $4^{0} \mathrm{C}$ throughout the period of the experiment.

\section{Standardization of the extracts}

The two extracts were reconstituted with $10 \%$ DMSO (Dimethylsulphoxide) and distilled water following manufacturer's recommendation. Six fold serial dilutions were carried out before obtaining six different concentrations of $100 \mathrm{mg} / \mathrm{mL}, 50 \mathrm{mg} / \mathrm{mL}, 25 \mathrm{mg} / \mathrm{mL}, 12.50$ $\mathrm{mg} / \mathrm{mL}, 6.25 \mathrm{mg} / \mathrm{mL}$, and $3.13 \mathrm{mg} / \mathrm{mL}$.

\section{Standardization of the inocula}

Mueller-Hinton Agar (MHA) served as a medium for sub-culturing the isolates on newly purchased sterile plates. The plates were incubated at $37^{\circ} \mathrm{C}$ for 24 hours and thereafter preserved at $4^{\circ} \mathrm{C}$ for subsequent overnight culturing from which isolates were later suspended in broth culture for antimicrobial assay. The broth cultures of the isolates were adjusted to the exact turbidity equivalent to $0.5 \mathrm{McF}$ arland Standard as recommended by NCCLS, (1998).

\section{Antimicrobial Assay}

Antimicrobial activity of the extracts was determined using agar well diffusion assay method (Thitilertdecha et al., 2008 and Ameya et al., 2016). Mueller Hinton Agar (MHA) was 
prepared as recommended by the manufacturer and allowed to cool to $50^{\circ} \mathrm{C}$ before pouring on pre-labelled sterile petri plates on a level surface. One petri-plate was prepared per organism and done in triplicates except that of the positive test control using Maxi discs that was done in duplicate. Sterile $6 \mathrm{~mm}$ borer was used to punch seven equidistant wells: wells $1-6$ for different concentrations of extracts $(3.13 \mathrm{mg} / \mathrm{mL}-100 \mathrm{mg} / \mathrm{mL})$. Well number seven (7) was bored at the centre of the plates for the solvent used (negative control). A dip with sterile swabbing sticks of overnight broth cultures of each of the isolates was streaked on the surface of the prepared MHA plates. The volume of $0.2 \mathrm{~mL}$ of the extracts at preset concentration was introduced to each of the wells and the plates were allowed to rest (and set) on the laboratory bench for 45 minutes allowing for proper pre-diffusion of the extracts before 24 hours incubation at $37^{\circ} \mathrm{C}$.

\section{Antibacterial activity}

The antimicrobial activities of the extracts were assessed by measuring the inhibition zones around the wells with the aid of a graduated transparent metre rule. There was no observed antimicrobial activity against the test organisms in the solvent used (DMSO 10\%) for the extracts' reconstitution as indicated by zero inhibition zones.

\section{Minimum Inhibitory Concentrations (MICs)}

The Minimum Inhibitory Concentration (MIC) is the lowest concentration of an antimicrobial that inhibits the growth of a microorganism after an overnight incubation. The MICs were determined by tube dilution (12-fold) method (Benger et al., 2004, Manilal et al., 2010 and Kaya et al., 2012) with slight modifications.

\section{Results and Discussion}

The results of the leaf processing percentage yield (LPPY), mean values for the antimicrobial activity and Minimum Inhibitory Concentrations (MICs) of the ethanolic leaf extract of $H$. asper and $H$. sabdariffa are presented in Table 1 to 4 . Leaf processing percentage yield was higher in H. asper $(22.86 \%)$ than H. sabdariffa $(15.83 \%)$ as seen in Table 1 . There is virtually no adduceable reason(s) for this as at now, because researchers in medicinal plants have not been reporting this aspect of work in literatures.

\section{Hibiscus asper}

Antimicrobial activity of ethanolic leaf extract of $H$. asper was more evident in BCE having the highest inhibition zone (Table 2$)$ with significant difference $(\mathrm{p}<0.05)$ over other isolates in descending order of BCE $\left(15.00 \pm 1.00^{\mathrm{a}}\right)>\operatorname{ECO}\left(11.67 \pm 0.58^{\mathrm{b}}\right)>\operatorname{SAU}\left(7.67 \pm 0.58^{\mathrm{c}}\right)$ $>$ PAE $\left(6.67 \pm 0.58^{\mathrm{d}}\right)>\operatorname{STY}\left(5.67 \pm 0.58^{\mathrm{e}}\right)$. The susceptibility of ECO and STY to the extract of $H$. asper in the present study agrees with earlier report of its antibacterial property against some Gram-negative bacteria (Ateufack et al., 2014). The extract can be described as broad spectrum because of its antibacterial effect on the Gram-positive (BCE and SAU) and Gramnegative isolates (ECO, PAE and STY) in this study. The sensitivity of SAU here disagrees with the resistance of SAU to the exctracts of $H$. asper as reported by Ateufack et al. (2014). 
The extract did not show any activity on PVU, KAE and MCA in the present study as shown in Table 2.

\section{Hibiscus sabdariffa}

The extract of $H$. sabdariffa was active on all the tested bacterial isolates (Table 3 ) with the exception of STY. The antibacterial potential of this plant as witnessed in the present study agrees with the reports on it against ECO, PAE, PVU, and SAU (Khalid et al., 2015), ECO (Fullerton et al., 2011), ECO and SAU (Higginbotham et al., 2014). The highest mean zone of inhibition displayed by the tested bacteria was found in BCE $\left(15.33 \pm 1.15^{\mathrm{a}}\right)$ followed by MCA $\left(11.33 \pm 1.15^{\mathrm{b}}\right)$, SAU $\left(11.00 \pm 1.00^{\mathrm{bc}}\right), \operatorname{KAE}\left(9.67 \pm 0.58^{\mathrm{c}}\right)$, PAE $\left(8.00 \pm 1.00^{\mathrm{d}}\right)$ and PVU $(7.67$ $\pm 0.57^{\mathrm{e}}$ ). This highest activity on BCE (Gram-positive) corroborates the earlier report on the extract of $H$. sabdariffa to be more active on Gram-positive bacteria (Khalid et al., 2015). Only STY showed resistance to the ethanolic leaf extract of $H$. sabdariffa. The earlier report of the preliminary phytochemical screening of H. asper and H. sabdariffa indicated the presence of tannins, flavonoids, saponnins, steroids and terpenoids in both samples and the absence of phlobatannins, alkaloids and anthraquinones (Arogbodo and Ajayi, 2020). The absence of alkaloids in H. sabdariffa agrees with the phytochemical report of Adamu and Ngwu (2015). Cardiac glycosides were present in $H$. asper but absent in H. sabdariffa. The phytochemicals (qualitatively and quantitatively) were found to be higher in $H$. asper than $H$. sabdariffa (Arogbodo and Ajayi, 2020). The observed antibacterial potential of ethanolic leaf extracts of $H$. asper and H. sabdariffa on both Gram-positive and Gram-negative bacteria can be attributed to their rich phytochemicals like the flavonoids (Elmanam et al., 2011; VimalinHena, 2010).

\section{Antimicrobial resistance}

PAE, PVU, SAU, ECO, MCA and STY were all resistant to the commercial antibiotic Septrin used as positive control in this experiment while only KAE and BCE were sensitive. On the other hand, all the tested bacteria were resistant to Amoxicillin (positive control) with the exception of PAE. The multidrug resistance of PAE, ECO and SAU to Septrin and that of ECO and SAU to Amoxicillin in this study agrees with the findings of Osuntokun and Adesemoye (2019), which is the current global problem (antimicrobial resistance).

\section{Minimum inhibitory concentrations (MICs)}

The minimum inhibitory concentration for PAE in both extracts (Table 4) was 25 $\mathrm{mg} / \mathrm{mL}$. PVU, KAE and MCA were resistant to H. asper but all had the same MIC of $25 \mathrm{mg} / \mathrm{mL}$ in the extract of $H$. sabdariffa. SAU, BCE and ECO MICs were $25 \mathrm{mg} / \mathrm{mL}, 6.25 \mathrm{mg} / \mathrm{mL}$, and $25 \mathrm{mg} / \mathrm{mL}$ in $H$. asper, but $12.25 \mathrm{mg} / \mathrm{mL}, 12.25 \mathrm{mg} / \mathrm{mL}$ and $50 \mathrm{mg} / \mathrm{mL}$ in $H$. sabdariffa respectively. STY MIC in $H$. asper was $25 \mathrm{mg} / \mathrm{mL}$ but showed no activity in the extract of $H$. sabdariffa. The MIC of 25 and $50 \mathrm{mg} / \mathrm{mL}$ for ECO in this study agrees with that of Jung et al. (2013) who reported same for ECO in aqueous extract of $H$. sabdariffa

Table 1: Leaf processing percentage yield (LPPY) of H. asper and H. Sabdariffa

\begin{tabular}{|l|l|l|l|}
\hline Medicinal plants & Fresh weight & Dry weight & Yield \% \\
\hline
\end{tabular}




\begin{tabular}{|l|l|l|l|}
\hline H. asper & 280 & 64 & 22.86 \\
\hline H. sabdariffa & 417 & 66 & 15.83 \\
\hline
\end{tabular}

Table 2: Mean values ( $\mathrm{mm}$ ) of inhibition zone diameters of ethanolic leaf extract of $H$. asper against the selected pathogenic bacteria

\begin{tabular}{|c|c|c|c|c|c|c|c|c|c|c|}
\hline \multirow[b]{2}{*}{ SN } & \multirow[b]{2}{*}{ Isolates } & \multicolumn{8}{|c|}{ Mean zones of inhibition (mm) } & \multirow[b]{2}{*}{$\begin{array}{l}\text { DMSO } \\
10 \%\end{array}$} \\
\hline & & C1 & $\mathrm{C} 2$ & C3 & $\mathrm{C} 4$ & C5 & C6 & $\begin{array}{l}\text { SXT } \\
(30 \mu \mathrm{g})\end{array}$ & $\begin{array}{l}\mathbf{A M} \\
(30 \mu \mathrm{g})\end{array}$ & \\
\hline 1 & PAE & $\begin{array}{l}6.67 \pm \\
0.58^{\mathrm{d}}\end{array}$ & $\begin{array}{l}4.33 \pm \\
0.58^{\mathrm{bc}}\end{array}$ & $\begin{array}{l}2.33 \pm \\
0.58^{\mathrm{bc}}\end{array}$ & - & - & - & $\mathrm{R}$ & 14 & NIL \\
\hline 2 & PVU & $\mathrm{R}$ & $\mathrm{R}$ & $\mathrm{R}$ & $\mathrm{R}$ & $\mathrm{R}$ & $\mathrm{R}$ & $\mathrm{R}$ & $\mathrm{R}$ & NIL \\
\hline 3 & KAE & $\mathrm{R}$ & $\mathrm{R}$ & $\mathrm{R}$ & $\mathrm{R}$ & $\mathrm{R}$ & $\mathrm{R}$ & 12 & $\mathrm{R}$ & NIL \\
\hline 4 & SAU & $\begin{array}{l}7.67 \quad \pm \\
0.58^{\mathrm{c}}\end{array}$ & $\begin{array}{ll}3.33 & \pm \\
0.58^{\mathrm{c}} & \end{array}$ & $\begin{array}{l}2.33 \pm \\
0.58^{\mathrm{bc}}\end{array}$ & - & - & - & $\mathrm{R}$ & $\mathrm{R}$ & NIL \\
\hline 5 & $\mathrm{BCE}$ & $\begin{array}{l}15.00 \pm \\
1.00^{\mathrm{a}}\end{array}$ & $\begin{array}{l}13.67 \pm \\
0.58^{\mathrm{a}}\end{array}$ & $\begin{array}{l}12.33 \pm \\
0.58^{\mathrm{a}}\end{array}$ & $\begin{array}{l}10.00 \pm \\
1.00\end{array}$ & $\begin{array}{l}6.33 \\
\pm 0.58\end{array}$ & - & 12 & $\mathrm{R}$ & NIL \\
\hline 6 & ECO & $\begin{array}{l}11.67 \pm \\
0.58^{\mathrm{b}}\end{array}$ & $\begin{array}{ll}8.33 & \pm \\
0.58^{\mathrm{b}} & \end{array}$ & $\begin{array}{ll}5.67 & \pm \\
0.58^{\mathrm{b}} & \end{array}$ & - & - & - & $\mathrm{R}$ & $\mathrm{R}$ & NIL \\
\hline 7 & MCA & $\mathrm{R}$ & $\mathrm{R}$ & $\mathrm{R}$ & $\mathrm{R}$ & $\mathrm{R}$ & $\mathrm{R}$ & $\mathrm{R}$ & $\mathrm{R}$ & NIL \\
\hline 8 & STY & $\begin{array}{l}5.67 \pm \\
0.58^{\mathrm{e}}\end{array}$ & $\begin{array}{l}4.33 \pm \\
0.58^{\mathrm{bc}}\end{array}$ & $\begin{array}{l}2.67 \pm \\
0.58^{\mathrm{bc}}\end{array}$ & - & - & - & $\mathrm{R}$ & $\mathrm{R}$ & NIL \\
\hline
\end{tabular}

Mean values with different superscript along the same row are significantly different from each other $(p<0.05)$. Values are mean \pm Standard deviation of triplicate determination of inhibition zones less the diameter of borer. Where $\mathrm{C} 1=100 \mathrm{mg} / \mathrm{mL}, \mathrm{C} 2=50 \mathrm{mg} / \mathrm{mL}, \mathrm{C} 3=25$ $\mathrm{mg} / \mathrm{mL}, \quad \mathrm{C} 4=12.5 \mathrm{mg} / \mathrm{mL}, \mathrm{C} 5=6.25 \mathrm{mg} / \mathrm{mL}, \quad \mathrm{C} 6=3.13 \mathrm{mg} / \mathrm{mL}$, PAE $=$ Pseudomonas aeruginosa, $\mathrm{PVU}=$ Proteus vulgaris, $\mathrm{KAE}=$ Klebsiella aerogenes, $\mathrm{SAU}=$ Staphylococcus aureus, $\mathrm{BCE}=$ Bacillus cereus, $\mathrm{ECO}=$ Escherichia coli, $\mathrm{MCA}=$ Moraxella catarrhalis, STY $=$ Salmonella typhi, $\mathrm{SXT}=$ Septrin, $\mathrm{AM}=$ Amoxicillin, $\mathrm{DMSO}=$ Dimethylsulphoxide and $\mathrm{R}=$ Resistant.

Table 3: Mean values (mm) of inhibition zone diameters of ethanolic leaf extract of $H$. sabdariffa against the selected pathogenic bacteria

\begin{tabular}{|c|c|c|c|c|c|c|c|c|c|c|}
\hline & \multirow[t]{2}{*}{ Isolates } & \multicolumn{8}{|c|}{ Mean zones of inhibition (mm) } & \multirow[b]{2}{*}{$\begin{array}{l}\text { DMSO } \\
10 \%\end{array}$} \\
\hline SN & & C1 & $\mathrm{C2}$ & $\mathbf{C 3}$ & C4 & $\mathbf{C 5}$ & C6 & $\begin{array}{l}\text { SXT } \\
(30 \mu \mathrm{g})\end{array}$ & $\begin{array}{l}\text { AM } \\
(30 \mu \mathrm{g})\end{array}$ & \\
\hline 1 & PAE & \begin{tabular}{ll|}
8.00 & \pm \\
$1.00^{\mathrm{d}}$ & \\
\end{tabular} & $7.67 \pm 0.58^{\mathrm{cd}}$ & $\begin{array}{lr}6.33 & \pm \\
0.58^{\mathrm{bc}} & \end{array}$ & - & - & - & $\mathrm{R}$ & 14 & NIL \\
\hline 2 & PVU & $\begin{array}{ll}7.67 & \pm \\
0.57^{\mathrm{e}} & \end{array}$ & $6.00 \pm 0.00^{\mathrm{e}}$ & $\begin{array}{ll}4.33 & \pm \\
0.58^{\mathrm{d}} & \\
\end{array}$ & - & - & - & $\mathrm{R}$ & $\mathrm{R}$ & NIL \\
\hline 3 & KAE & $\begin{array}{ll}9.67 & \pm \\
0.58^{\mathrm{c}} & \\
\end{array}$ & $8.00 \pm 0.00^{c}$ & $\begin{array}{ll}4.00 & \pm \\
0.00^{\mathrm{d}} & \\
\end{array}$ & - & - & - & 12 & $\mathrm{R}$ & NIL \\
\hline 4 & SAU & \begin{tabular}{ll|}
11.00 & \pm \\
$1.00^{\mathrm{bc}}$
\end{tabular} & $6.67 \pm 1.15^{\mathrm{de}}$ & $\begin{array}{ll}6.00 & \pm \\
0.00^{\mathrm{c}} & \\
\end{array}$ & $\begin{array}{ll}3.00 \quad \pm \\
1.00^{\mathrm{b}}\end{array}$ & - & - & $\mathrm{R}$ & $\mathrm{R}$ & NIL \\
\hline 5 & $\mathrm{BCE}$ & \begin{tabular}{ll|}
15.33 & \pm \\
$1.15^{\mathrm{a}}$ & \\
\end{tabular} & $\begin{array}{ll}13.33 & \pm \\
1.15^{\mathrm{a}} & \end{array}$ & $\begin{array}{ll}7.33 & \pm \\
1.15^{\mathrm{a}} & \end{array}$ & $\begin{array}{l}3.00 \pm \\
1.00^{\mathrm{a}}\end{array}$ & - & - & 12 & $\mathrm{R}$ & NIL \\
\hline
\end{tabular}




\begin{tabular}{|c|c|c|c|c|c|c|c|c|c|c|}
\hline 6 & ECO & $\begin{array}{l}3.00 \\
\pm 1.00^{\mathrm{f}}\end{array}$ & $2.00 \pm 0.00^{\mathrm{f}}$ & - & - & - & - & $\mathrm{R}$ & $\mathrm{R}$ & NIL \\
\hline 7 & MCA & $\begin{array}{ll}11.33 & \pm \\
1.15^{\mathrm{b}} & \end{array}$ & $9.33 \pm 1.15^{b}$ & $\begin{array}{ll}4.67 & \pm \\
1.15^{\mathrm{d}} & \end{array}$ & - & - & - & $\mathrm{R}$ & $\mathrm{R}$ & NIL \\
\hline 8 & STY & $\mathrm{R}$ & $\mathrm{R}$ & $\mathrm{R}$ & $\mathrm{R}$ & $\mathrm{R}$ & $\mathrm{R}$ & $\mathrm{R}$ & $\mathrm{R}$ & NIL \\
\hline
\end{tabular}

Mean values with different superscript along the same row are significantly different from each other $(p<0.05)$. Values are mean \pm Standard deviation of triplicate determination of inhibition zones less the diameter of borer. Where $\mathrm{C} 1=100 \mathrm{mg} / \mathrm{mL}, \mathrm{C} 2=50 \mathrm{mg} / \mathrm{mL}, \mathrm{C} 3=25$ $\mathrm{mg} / \mathrm{mL}, \mathrm{C} 4=12.5 \mathrm{mg} / \mathrm{mL}, \mathrm{C} 5=6.25 \mathrm{mg} / \mathrm{mL}, \mathrm{C} 6=3.13 \mathrm{mg} / \mathrm{mL}$, PAE $=$ Pseudomonas aeruginosa, $\mathrm{PVU}=$ Proteus vulgaris, $\mathrm{KAE}=$ Klebsiella aerogenes, $\mathrm{SAU}=$ Staphylococcus aureus, $\mathrm{BCE}=$ Bacillus cereus, $\mathrm{ECO}=$ Escherichia coli, $\mathrm{MCA}=$ Moraxella catarrhalis, STY $=$ Salmonella typhi, $\mathrm{SXT}=$ Septrin, $\mathrm{AM}=$ Amoxicillin, $\mathrm{DMSO}=$ Dimethylsulphoxide and $\mathrm{R}=$ Resistant.

Table 4: Minimum inhibitory concentrations (MICs) of Hibiscus asper and Hibiscus sabdariffa on the selected bacterial isolates

\begin{tabular}{|l|l|l|l|}
\hline SN & Bacterial isolates & H. asper $(\mathrm{mg} / \mathrm{mL})$ & H. sabdariffa $(\mathrm{mg} / \mathrm{mL})$ \\
\hline 1 & Pseudomonas aeruginosa $($ PAE) & 25 & 25 \\
\hline 2 & Proteus vulgaris (PVU) & $\mathrm{R}$ & 25 \\
\hline 3 & Klebsiella aerogenes $($ KAE) & $\mathrm{R}$ & 25 \\
\hline 4 & Staphylococcus aureus $($ SAU) & 25 & 12.5 \\
\hline 5 & Bacillus cereus (BCE) & 6.25 & 12.5 \\
\hline 6 & Escherichia coli (ECO) & 25 & 50 \\
\hline 7 & Moraxella catarrhalis (MCA) & $\mathrm{R}$ & 25 \\
\hline 8 & Salmonella typhimurium $(S T Y)$ & 25 & $\mathrm{R}$ \\
\hline
\end{tabular}

\section{Conclusion and Suggestion}

The two-plant species demonstrated antibacterial potential on both Gram-positive and Gram-negative bacteria in this study. However, H. sabdariffa was more active as it showed antibacterial activity on seven bacteria as against $H$. asper that was on five out of the eight experimented isolates. The antibacterial effect of the extracts from both plants was greatest on BCE with mean inhibition zones diameter of $15.00 \pm 1.00^{\mathrm{a}} \mathrm{mm}$ and $15.33 \pm 1.15^{\mathrm{a}} \mathrm{mm}$ in $H$. asper and $H$. sabdariffa respectively. The MIC of BCE was lower in $H$. asper $(6.25 \mathrm{mg} / \mathrm{mL})$ than $H$. sabdariffa $(12.5 \mathrm{mg} / \mathrm{mL})$. Based on the outcome of this experiment, $H$. asper and $H$. sabdariffa are therefore suggested as potential anti-bacteria sources to be reckoned with for further research in herbal antimicrobial drug formulation by pharmaceutical industries both for human usage and in animal husbandry. Testing of the bacterial isolates with higher extracts' concentrations can be evaluated for the possibility of better results.

Acknowledgements

None 


\section{Conflict of Interest}

The authors have no competing interest to declare.

\section{Funding}

None was received to carry out the experiments.

\section{References}

Adamu, H. and Ngwu, R.O. (2015). Phytochemical screening and antibacterial activities of Hibiscus sabdariffa. Nigerian Journal of Chemical Research, Volume 20 pp 46 - 52.

Adel, M., Kelly, M., Samantha, T., Lynn, F., Brenda, T., Jun, W., Heba, M., Sharon, P., Archibald, P., Paul, G., Dwight, H. and Nicole, P. (2019). Nextgeneration-sequencingbased hospital outbreak investigation yields insight into Klebsiella aerogenes population structure and determinants of carbapenem resistance and pathogenicity. Antimicrob Agents Chemother 63:02577-18. https://doi.org/10.1128/AAC .02577-18.

Ameya, G., Gure, A. and Dessalegn, E. (2016). Antimicrobial activity of Echinops Kebericho against human pathogenic bacteria and fungi. Afri. J. Tradit Complement Altern Med 13(6): $199-203$.

Anna, B., Antoni, P., Garbowska, M. and Ilona, S. (2019). Prevalence and Toxicity Characterization of Bacillus cereus in Food Products from Poland. Foods 2019, 8, 269; doi:10.3390/foods 8070269 www.mdpi.com/journal/foods

Arogbodo, J. O. and Ajayi, O. A. (2020). Comparative study of the phytochemical, proximate and mineral constituents of air-dried leaves of Hibiscus asper and Hibiscus sabdariffa. $45^{\text {th }}$ Annual Conference of Nigerian Society for Animal Production Book of Proceedings, (Bauchi 2020). Pp 398 - 402.

Ateufack, G., Nana, Y. W., Dongmo, F. B. R., Fonkeng, S. L., Kuiate, J. R. and Kamanyi, A. (2014). Antidiarrhoeal and In vitro Antibacterial Activities of Leaves Extracts of Hibiscus asper Hook. F. (Malvaceae). Asian Journal of Pharmaceutical and Clinical Research. 7(4): 130 - 136. 2014 ISSN - 0974-2441

Benger, S., Townsend, P., Ashford, R. L. and Lambert, P. (2004). An in vitro study to determine the minimum inhibitory concentration of Melaleuca alternifolia against the dermatophyte Trichophyton rubrum. Foot 2004; 14(2): 86 - 91.

Bireswar, B. and Charu, S. (2018). Potential Bioactive Properties of Hibiscus sabdariffa (Roselle). World Journal of Pharmacy and Pharmaceutical Sciences 7(10): 718 - 734.

Burkill, H. M. (1985). The Useful Plants of West Tropical Africa. Vol. 1. Kew, England: Scientific Publications Department, Royal Botanic Gardens; 1985. Pp 1.

Burkill, H. M. (1997). The useful plants of West Tropical Africa. 2nd edition volume 4 families, M-R, Royal Botanical Gardens, Ken, United Kingdom. Pp : 969.

Chandran, A. and Mazumder, A. (2015). Pathogenic potential, genetic diversity, and population structure of Escherichia coli strains isolated from a forest-dominated watershed (Comox lake) in British Columbia, Canada. Appl Environ Microbiol 81, 1788 - 1798.

Debasis, M., Sandeep, K. D., Balaram, D., Manideepa, S., Pratip, K. K. and Somenath, R. (2015). Isolation and Characterization of Multi-Drug Resistance Proteus vulgaris 
from Clinical Samples of UTI Infected Patients from Midnapore, West Bengal. International Journal of Life Science and Pharma Research 5(2): 32- 45.

Elmanam, A. A., Alyazji, A. A. and Abu, G. N. A. (2011). Antibacterial, antifungal and synergistic effect of Lawsonia inermis, Punica grantum and Hibiscus sabdariffa. Ann Alquds Med, 7:33 - 41.

Encyclopedia britannica (2020). 'Roselle-plant' Written by the Editors of Encyclopedia Britannica C 2020, inc. Accessed on 26/03/2020.

Foyet, H. S., Abdou, B. A., Ponka, R., Asongalem, A. E., Kamtchouing, P. and Nastasa, V. (2011). Effects of Hibiscus asper leaves extracts on carrageenan induced arthritis in rats. J Cell Anim Biol 2011; 5(5):69-75.

Fullerton, M., Khatiwada, J., Johnson, J. U., David, S. and Williams, L. L. (2011). Determination of antimicrobial activity of sorrel (Hibiscus sabdariffa) on Escherichia coli O157: H7 isolated from food, veterinary, and clinical samples. Journal of medicinal food, 14(9): 950 - 956.

Granum, P. E. (1997). Bacillus cereus and its toxins. J. Appl. Bacteriol. Symp. Suppl. 76, 61S $-66 \mathrm{~S}$.

Higginbotham, K. L., Burris, K. P., Zivanovics, S., Davidson, P. M. and Stewart, Jr C. N. (2014). Antimicrobial activity of Hibiscus sabdariffa aqueous extracts against Escherichia coli O157: H7 and Staphylococcus aureus in a microbiological medium and milk of various fat concentrations. Journal of food protection, 77(2): $262-268$.

Hritcu, L., Foyet, H. S., Stefan, M., Mihasan, M., Asongalem, A. E. and Kamtchouing, P. (2011). Neuroprotective effect of the methanolic extract of Hibiscus asper leaves in 6-hydroxydopamine-lesioned rat model of Parkinson's disease. J Ethnopharmacol 2011; 137(1):585-91.

Hugo, W. B. and Russell, A. D. (1998). Pharmaceutical Microbiology, $6^{\text {th }}$ edition Black well Science Ltd. Osney Mead Oxford OX” 25 John Street, London WCIN 6AJ.

Jang, J., Hur, H., Sadowsky, M. J., Byappanahalli, M. N., Yan, T and Ishii, S. (2017). Environmental Eschericia coli: ecology and public health implications - a review. Journal of Applied Microbiology 123, 570 - 581.

Jing, Z., Thomas, S. V., Yue, G., Yadang, Qi., Kit, C., Min-Hsiung, P., Chi-Tang, Ho., James, E. S and Qinghli, W. (2015). "Phytochemistry, antioxidant capacity, total phenolic content and anti-inflammatory activity of Hibiscus sabdariffa leaves." Food chemistry 190 (2016): 673-680

Jung, E., Kim, Y. and Joo, N. (2013). Physicochemical Properties and antimicrobial activity of Roselle (Hibiscus sabdariffa L.). Journal of the Science of Food and Agriculture, 93(15): 3769 - 3776.

Kaper, J. B., Nataro, J. P. and Mobley, H. L. T. (2004). Pathogenic Escherichia coli. Nat Rev Microbiol 2, 123 - 140.

Kaya, O., Akcam, F. and Yayh, G. (2012). Investigation of the in vitro activities of various antibiotics against Brucella melitensis strains. Turk J. Med Sci. 2012; 42: 145 - 148.

Khalid, S. A., Suliman, I. S., Ismail, A. Z. and Nasr El-Deen, A. H. (2015). Antimicrobial potential of methanolic extracts of Hibiscus sabdariffa and Ricinus communis. Advancement in Medicinal Plant Research, 3(1): 18 - 22. 
Kramer, J. M. and Gilbert, R. J. (1989). Bacillus cereus and other Bacillus species In: Food borne Bacterial Pathogens (Doyle, M. P., ED), pp 21 - 70. Marcel Dekker, New York.

Lee, K. M., Runyon, M., Herrman, T. J, Philips, R. and Hsieh, J. (2015). Review of Salmonella detection and identification methods: Aspects of rapid emergency response and food safety. Food Control, 47: 264 - 276.

Lund, T. and Granum, P. E. (1997). Comparison of biological effect of the two different enterotoxin complexes isolated from three different strains of Bacillus cereus. Microbiology 143, $3329-3339$.

Manilal, A., Sujith, S., Kiran, G. S., Selvin, J., Shakir, C. and Lipton A. P. (2010). Antimicrobial potential of marine organisms collected from the southwest coast of India against multiresistant human and shrimp pathogens. Sci. Mar 2010; 74(2): 287 $-296$.

Mohamed, R., Fernandez, J., Pineda, M. and Aguilar M. "Roselle (Hibiscus sabdariffa) seed oil is a rich source of gamma-tocopherol." Journal of Food Science 72(3):S207-11, 2007 Apr.

NCCLS (1998). National Committee for Clinical Laboratory Standard (NCCLS). Methods for dilution in antimicrobial susceptibility test, Villanova.

Ofongo, R. T. S and Ohimain, E. I. (2019). Effect of enzyme supplementation and plant extracts on villus height and microbial counts in broilers. Nig. J. Anim. Prod. 2019, 46(2): 137 -149 .

Ogunleye, A. O. and Carlson, S. (2016). Drug Resistant Proteus mirabilis and Proteus vulgaris Isolated from Rats Captured from Some Poultry Houses in Ibadan, Oyo State, Nigeria and their Public Health Importance. Afr. J. Biomed. Res. Vol.19; 261- 266.

Oladipo, T. A., Adeleye, O. E., Olorode, J., Adebiyi, A. A., Omobowale, O. O., Adeoye, Y. D., Adenubi, O. T., Oladipo, O. O and Olukunle, J. O. (2019). Diabetogenic potential of dexamethasone and effect Annona muricata methanolic bark extract as post-exposure therapy in albino rats. Nig. J. Anim. Prod. 2019, 46(2): 72 - 79.

Osuntokun, O. T. and Adesemoye, Y. O. (2019). Efficacy of Nigerian Medicinal Plant (Olax Subscorpioidea. Oliv.) Root Extract against Surgical Wound Isolates. American Journal of Microbiology and Biochemistry, 2(1): 001 - 011.

Per, E. G. and Terje, L. (1997). Bacillus cereus and its food poisoning toxins. FEMS Microbiology letters 157, 223 - 228.

Savitha, R.,Gauri, K., Sivanandan, R. N. and Dias M. (2020). Moraxella catarrhalis: A Cause of Concern with Emerging Resistance and Presence of BRO Beta-Lactamase GeneReport from a Tertiary Care Hospital in South India. Hindawi International Journal of Microbiology Volume 2020, Article ID 7316257, 5 pages https://doi.org/10.1155/2020/7316257

Shamshul, A., Rajesh, K. J., Shyam, K. M., Birendra, R. T. and Ahmed, M. A. (2019). Recent advances in Staphylococcus aureus infection: focus on vaccine development- a review. Published by Dove Medical Press Limited. Infection and Drug Resistance vol. 12 pp $1243-1255$.

Shippers, R. R. and Bosh, C. H. (2004). Hibiscus asper Hook.f. fiche de protabase. In: Grubben GJ, Denton OA, editors. PROTA Plant Resources of Tropical Africa/Resources Végétales de l'Afrique Tropicale. Pays-Bas: Wageningen; 2004. Pp 192. 
Sunilson, J. A., Anandarajagopal, K., Kumari, A. V. and Mohan S. (2009). Antidiarrhoeal activity of leaves of Melastoma malabathricum Linn. Indian J Pharm Sci 2009; 71(6):691-5.

Thitilertdecha, N., Teerawutgulrag, A. and Rakariyatham, N. (2008). Antioxidant and antibacterial activities of Nephelium Lappaceum L. extracts. LWT-Food Science and Technology. 2008; 41(10): 2029 - 2035.

Ukorebi, B. A., Akpet, S. O and Gbose, P. N. (2019). Haematology, serum biochemistry and organ histopathology of broiler chickens fed graded levels of Gongronema latifolia (Utasi). Nig. J. Anim. Prod. 2019, 46(2): $164-175$.

Verma, A. K. K., Neha, A. R. A. and Bist, B. (2014). Multi Drug Resistant Pseudomonas Aeruginosa: A secondary invader and Cause of Mortality in Foot and Mouth Disease Outbreak. Global Journal of Medical Research: G veterinary Science and Veterinary Medicine 14 (3): 6 - 9.

VimalinHena, J. (2010). Antibacterial potentiality of Hibiscus rosa-sinensis solvent extracts and aqueous extracts against some pathogenic bacteria. Herbal Tech Industry, 6(11): $21-23$.

Wumnokol, D. P., Guluwa, L. Y and Latu, M. Y. (2019). Performance and Haematology of broiler starter fed Acha (Digitaria exilis staph) grains as replacement for maize. Nig. J. Anim. Prod. 2019, 46(2): 87 - 91.

Yang, B., Qu, D., Zhang, X., Shen, J., Cui, S., Shi, Y., Xi, M., Sheng, M., Zhi, S. and Meng, J. (2010). Prevalence and characterization of Salmonella serovars in retail meats of market-place in Shaanxi, China. Int. J. Food Microbiol., 141 (1 - 2): 63 - 72. 